\title{
Rancang Bangun Smart pH Meter Sebagai Alat Ukur Pemantau Larutan Nutrisi
}

\author{
FEBRIAN HADIATNA, RATNA SUSANA \\ Program Studi Teknik Elektro Institut Teknologi Nasional Bandung \\ Email : Febrian_Hadiatna@yahoo.com
}

Received 24 Desember 2018 | Revised 11 Februari 2019 | Accepted 20 Mei 2019

\begin{abstract}
ABSTRAK
Potential of Hydrogen $(\mathrm{pH})$ adalah salah satu parameter penting yang terdapat pada nutrisi tanaman hidroponik. Setiap tanaman memerlukan nutrisi dengan $\mathrm{pH}$ sesuai kebutuhannya, agar dapat tumbuh dengan baik. pH nutrisi akan berubah setiap saat, sehingga perlu sering dipantau. Terdapat kendala pada $\mathrm{pH}$ meter yang digunakan saat ini, misalnya perlu kalibrasi ulang jika digunakan lebih dari 24 Jam karena elektroda sensor $\mathrm{pH}$ rentan terhadap larutan yang diukurnya. Pada penelitian ini dirancang sebuah $\mathrm{pH}$ meter cerdas yang akan digunakan untuk mengukur nutrisi tanaman. Alat ukur ini mampu digunakan secara terus menerus selama lebih dari 24 jam. Sensor pH yang digunakan adalah FIT0348 dan ATMega8 sebagai unit kontrolernya. Proses pengujian terdiri dari 4 tahap. Berdasarkan hasil pengujian, disimpulkan bahwa koefisien determinasi pada rangkaian pengkondisi sinyal yang dirancang telah linier yaitu 0,9999 dengan persamaan regresi $y=0,0065 x+6,189 . \Delta p H$ dari $p H$ meter yang dirancang adalah $\pm 0,01$ dengan menggunakan PH/EC-9853 sebagai alat ukur pembandingnya.
\end{abstract}

Kata kunci: potensial of hydrogen, pH meter, hidroponik, nutrisi tanaman

\begin{abstract}
Potential of Hydrogen $(\mathrm{pH})$ is one of the important parameters found in hydroponic plant nutrition. Every plant needs nutrients with $\mathrm{pH}$ according to their needs, so they can grow well. The $\mathrm{pH}$ of nutrients will change at any time, so it needs to be monitored frequently. There is a problem with the $\mathrm{pH}$ meter used today, for example, it needs recalibration if it is used more than 24 hours because the $\mathrm{pH}$ sensor electrode is susceptible to the solution it measures. In this study, a smart $\mathrm{pH}$ meter was designed to be used to measure plant nutrient. This measuring instrument can be used continuously for more than 24 hours. The pH sensor used is FIT0348 and ATMega8 as the controller unit. The testing process consists of 4 steps. Based on tests, it was concluded that the coefficient of determination in the signal conditioning circuit designed was equal to 0.9999 with the regression equation $y=0.0065 x+6.189 . \Delta p H$ from the $\mathrm{pH}$ meter designed is \pm 0.01 by using PH/EC-9853 as a comparison measuring instrument.
\end{abstract}

Keywords: potensial of hydrogen, $\mathrm{pH}$ meter, hydroponic, plant nutrition 


\section{PENDAHULUAN}

Hidroponik merupakan salah satu metoda bercocok tanam dengan menggunakan air yang mengandung nutrisi serta oksigen terlarut sebagai media tanamnya (Roidah, 2014). Pada sistem hidroponik, nutrisi tanaman memiliki peranan penting, yang menunjang terhadap pertumbuhan tanaman. Nutrisi tanaman yang digunakan, terdiri dari berbagai kandungan unsur didalamnya, diantaranya nitrogen, kalium, fosfor, kalsium, magnesium, boron, besi, chlore, cobalt, potential of Hydrogen, dsb. Beberapa kandungan penting di nutrisi tanaman, pada umumnya akan selalu mengalami perubahan nilai setiap waktunya. Hal ini terjadi, dikarenakan adanya beberapa faktor yang mempengaruhi, diantaranya kemampuan tanaman dalam menyerap kandungan nutrisi, serta faktor lingkungan seperti temperature udara.

Pada beberapa kandungan nutrisi, saat ini telah mampu dilakukan proses pemantauan. Semakin banyak kandungan penting pada nutrisi tanaman yang dapat dipantau nilai besarannya, akan berdampak pada kualitas nutrisi tanaman yang dihasilkannya menjadi semakin baik. Salah satu kandungan pada nutrisi tanaman yang saat ini telah memungkinkan untuk dilakukan proses pengukuran adalah kandungan $\mathrm{pH}$ (potential of hydrogen). Pertumbuhan tanaman akan subur jika nilai $\mathrm{pH}$ nutrisinya berada pada nilai rentan yang diperlukannya. Setiap jenis tanaman, memerlukan nutrisi tanaman dengan nilai $\mathrm{pH}$ yang berbeda-beda.

Derajat keasaman atau $\mathrm{pH}$ adalah konsentrasi ion hidrogen yang sangat kecil, dimana $\mathrm{pH}$ didefinisikan sebagai logaritma basis -10 dari konsentrasi ion hydrogen (Shahrulakram, 2016). Pada beberapa aplikasi, diantaranya bidang kimia analis, kendali pada bidang biologi dan lain-lain biasanya diperlukan sebuah sistem pemantauan terhadap kandungan $\mathrm{pH}$ (Canals, 2000). Pada bidang biologi misalnya tanaman, kandungan pH dengan nilai tertentu pada nutrisi tanaman diperlukan, untuk menghasilkan pertumbuhan tanaman yang optimal. Kandungan $\mathrm{pH}$ yang berlebih atau kurang, mengakibatkan terhambatnya pertumbuhan tanaman. Derajat keasaman ini memiliki perubahan nilai dalam kurun waktu tertentu. Potential of Hydrogen akan berubah tidak menentu bergantung kepada faktorfaktor yang mempengaruhinya. Faktor tersebut diantaranya suhu, proses dekomposisi bahan organik, fotosintesi ataupun adanya unsur lain yang terendam kedalam air (Taufiqullah, 2017).

pH meter adalah alat ukur yang dapat memberikan informasi mengenai derajat keasaman suatu larutan. Alat ukur ini menggunakan sebuah probe yang terbuat dari silinder kaca nonkonduktor yang berfungsi sebagai sensornya. Dengan memanfaatkan senyawa $\mathrm{HCl}$ yang merendam kawat elektroda, alat ini mampu mengukur derajat keasaman yang terkandung dalam air (ONNY, 2017). pH meter yang ada saat ini memiliki dua tipe, berdasarkan lamanya waktu proses pencelupan terhadap larutan yang diukurnya. Tipe pertama tidak mampu digunakan selama lebih dari 24 jam dan perlu dilakukan proses kalibrasi ulang. Pada tipe kedua, telah mampu digunakan lebih dari 24 jam, namun ketepatannya akan berkurang setiap harinya.

Pengetahuan mengenai parameter $\mathrm{pH}$ sangat penting dalam membantu pemahaman pada proses, hal ini karena memiliki pengaruh yang besar pada banyak reaksi biologis dan kimia (Jun Li, 2015). Berdasarkan beberapa permasalahan yang terdapat pada proses penggunaan alat ukur pH meter, diantaranya proses kalibrasi, lifetime alat ukur, tingkat akurasi hasil pengukuran dan sebagainya. Beberapa faktor lain juga mempengaruhi terhadap hasil pengukuran $\mathrm{pH}$ meter, diantaranya adanya pengaruh lingkungan misalnya suhu mempengaruhi nilai $\mathrm{pH}$, operator yang menggunakannya, serta metode pengukuran yang 
dilakukannya (Sabat, 2017). Oleh karena itu, pada penelitian ini bermaksud untuk mengembangkan sebuah alat ukur pH meter yang bersifat cerdas. Kecerdasan yang akan di tanamkan pada alat ukur tersebut yaitu pada proses kalibrasi alat ukur, yaitu berupa mengurangi waktu kalibrasi ulang.

Adapun beberapa rumusan masalah yang terdapat pada penelitian ini, diantaranya: bagaimanakah cara perangkat mikrokontroler melakukan proses akuisisi data dari sensor $\mathrm{pH}$ ? serta berapakah penurunan nilai $\mathrm{pH}$ pada sensor $\mathrm{pH}$ yang terjadi setiap penggunaan 24 jam? Dalam penelitian ini, terdapat beberapa batasan yang dilakukan, diantaranya: tidak meneliti life time dari sensor $\mathrm{pH}$ yang digunakan, proses pengujian dilakukan dengan membandingkan sensor $\mathrm{pH}$ yang digunakan dengan alat ukur $\mathrm{PH} / \mathrm{EC}-9853$, larutan nutrisi yang digunakan pada proses pengujian diatur nilai $\mathrm{pH}$-nya dengan menambahkan larutan $\mathrm{pH}$ up dan $\mathrm{pH}$ down, jangkauan nilai $\mathrm{pH}$ yang di uji berkisar 2 sampai dengan 13 derajat keasaman, serta temperatur pada larutan yang digunakan di set stabil pada suhu kamar

\section{PERANCANGAN SISTEM}

\subsection{Perangkat Keras}

Pada penelitian ini, proses perancangan pada bagian perangkat keras $\mathrm{pH}$ meter adalah merancang sebuah rangkaian pengkondisi sinyal yang ditambah dengan unit kontroler. Berikut ini Gambar 1 yang menggambarkan blok diagram dari pH meter yang dirancang.

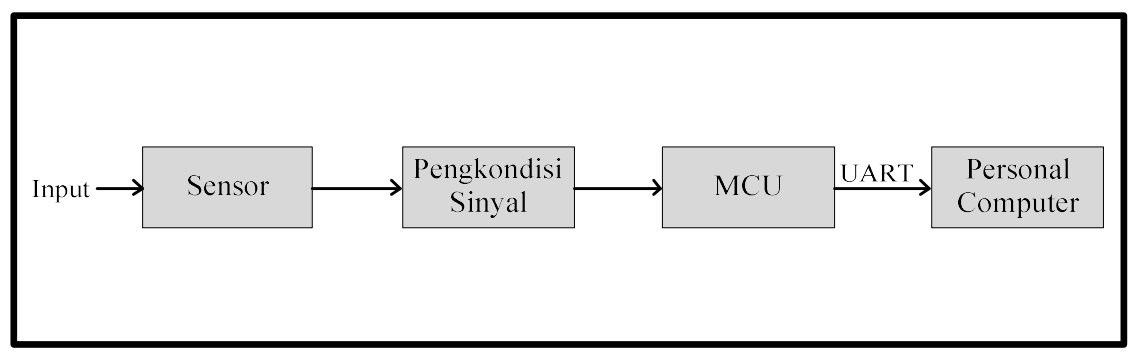

Gambar 1. Blok Diagram pH Meter (Banu,2017)

Berdasarkan Gambar 1, tampak bahwa pada sistem tersebut, terdapat unit sensor pH yang berfungsi untuk mengolah input yang berupa $\mathrm{pH}$ larutan air. Output data yang dihasilkan sensor tersebut berupa data analog yang nilainya relatif rendah, sehingga diperlukan sebuah rangkaian pengkondisi sinyal untuk memperbesar nilainya. Setelah data analog yang dihasilkan unit sensor tersebut telah cukup besar nilainya dari hasil penguatan yang dilakukan pada pengkondisi sinyal, selanjutnya akan diolah data tersebut oleh unit mikrokontroler. Mikrokontroler akan mengolah data tersebut, hingga menghasilkan informasi nilai $\mathrm{pH}$ dalam format data UART. Diperlukan sebuah personal computer (PC) untuk menampilkan informasi nilai pH tersebut dengan melalui aplikasi serial monitor.

Gambar 2 menunjukkan skematik dari rangkaian pengkondisi sinyal sensor pH yang digunakan. Berdasarkan Gambar 2, tampak bahwa pada rangkaian terdapat beberapa IC yang digunakan, diantaranya IC Voltage Converter TC1121 serta IC pengkondisi sinyal yang terdiri dari rangkaian amplifier CA3140AMZ dan TL081BCD64. 


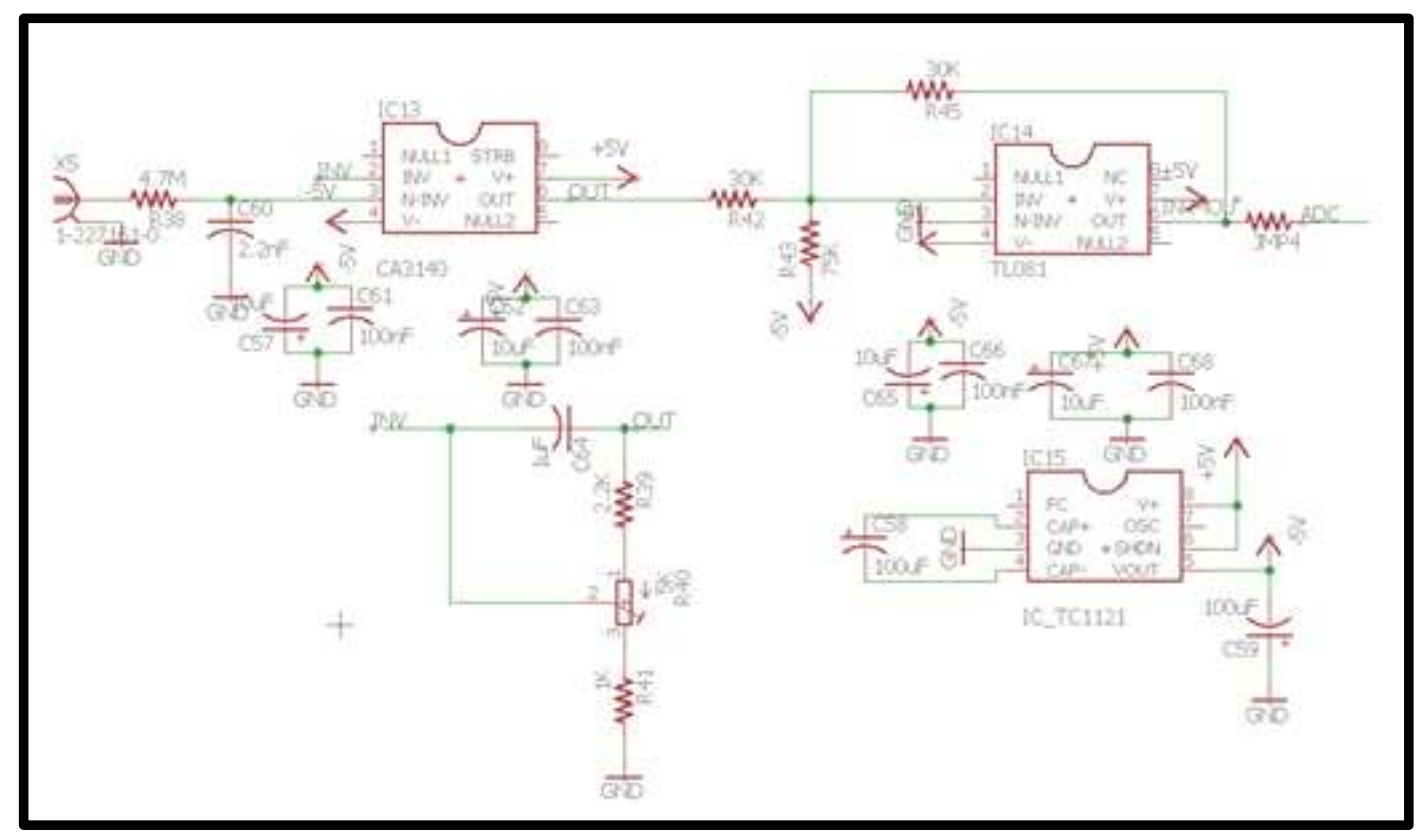

Gambar 2. Skema Rangkaian Pengkondisi Sinyal Sensor pH (Dfrobot, 2017)

Rangkaian pengkondisi sinyal yang di rancang berdasarkan pada referensi IC TC1121 digunakan untuk menghasilkan output berupa catu daya -5Volt. Catu daya negatif tersebut digunakan sebagai catu daya pada rangkaian pengkondisi sinyal yang memerlukan adanya catu daya negatif.

IC CA3140AMZ digunakan untuk proses penguatan sinyal yang dihasilkan sensor $\mathrm{pH}$. Output yang dihasilkan oleh sensor $\mathrm{pH}$ memiliki sinyal yang relatif kecil serta rentan terhadap noise. IC CA3140AMZ memiliki karakteristik very high input impedance dan very low input current. Output sinyal yang dihasilkan oleh IC CA3140AMZ masih cukup kecil, serta memungkinkan untuk menghasilkan output sinyal negatif yang tidak memungkinkan diolah oleh perangkat mikrokontroler.

Output sinyal yang dihasilkan IC CA314AMZ, selanjutnya menjadi input bagi IC TL081BCD64. IC ini digunakan sebagai penguatan sinyal, dengan menggunakan rangkaian summing amplifier (Dfrobot, 2017). Berikut ini Persamaan (1) yang digunakan pada rangkaian summing tersebut.

$$
V_{\text {out }}=\left(V_{\text {out } C A 314 A M Z}-2\right)
$$

Berikut ini Gambar 3, realisasi dari prototipe rangkaian pengkondisi sinyal yang telah dirancang.

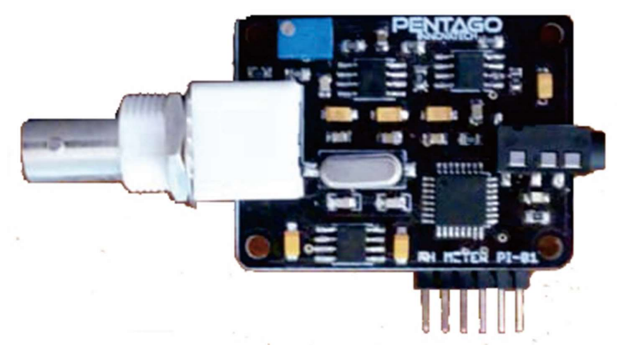

Gambar 3. Realisasi Prototipe Smart pH meter 


\subsection{Perangkat Lunak}

Pada perancangan perangkat lunak, algoritma program yang digunakan secara umum adalah terdiri dari proses kalibrasi serta akuisisi data. Berikut ini Gambar 4 yang memperlihatkan algoritma yang digunakan dalam bentuk flowchart program secara umum.

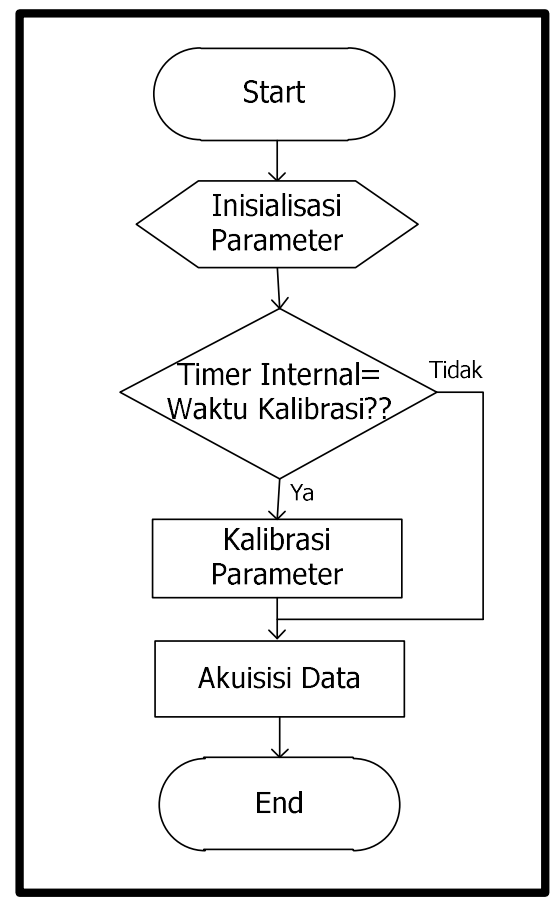

\section{Gambar 4. Flowchart Program Umum}

Berdasarkan flowchart pada Gambar 4, tampak bahwa smart pH meter yang dirancang pada dasarnya terintegrasi dengan pewaktu yakni dengan memanfaatkan internal timer pada perangkat mikrokontroler. Adapun penjelasan dari flowchart tersebut adalah sebagai berikut.

a. Inisialisasi Parameter. Pada proses ini dilakukan inisialisasikan nilai variabel dan konstanta yang akan digunakan.

b. Timer Internal=Waktu Kalibrasi?. Unit mikrokontroler akan melakukan pengecekan waktu, jika waktu yang terbaca menunjukkan waktu kalibrasi, maka selanjutnya akan dilakukan proses kalibrasi.

c. Kalibrasi Parameter. Nilai yang terdapat pada variabel kalibrasi mengalami perubahan pada proses ini, sehingga $\mathrm{pH}$ meter memungkinkan untuk menghasilkan pengukuran yang tetap presisi dan akurat pada waktu yang lama.

d. Akuisisi Data. Pada proses ini diterapkan sebuah algoritma yang berfungsi untuk menghasilkan pengukuran yang presisi dan akurat.

Pada proses kalibrasi parameter, terdapat sebuah nilai konstanta yang digunakan sebagai parameter pada proses kalibrasi yang akan mengalami perubahan nilainya berdasarkan waktu pemakaian sensor. Adapun besarnya nilai perubahan tersebut diperoleh berdasarkan hasil pengujian pada tahap ketiga. output yang dihasilkan pada rangkaian pengkondisi sinyal perlu diolah kembali agar menghasilkan $\mathrm{pH}$ meter yang presisi dan akurat, sehingga diperlukan unit mikrokontroler.

Pada proses akuisisi data, diperlukan sebuah algoritma yang dirancang untuk menghasilkan sebuah data hasil pengukuran yang mendekati nilai sebenarnya. Berikut ini Gambar 5 adalah 
algoritma yang digunakan pada proses akusisi data, yang telah diterapkan pada penelitian di tahun 2017.

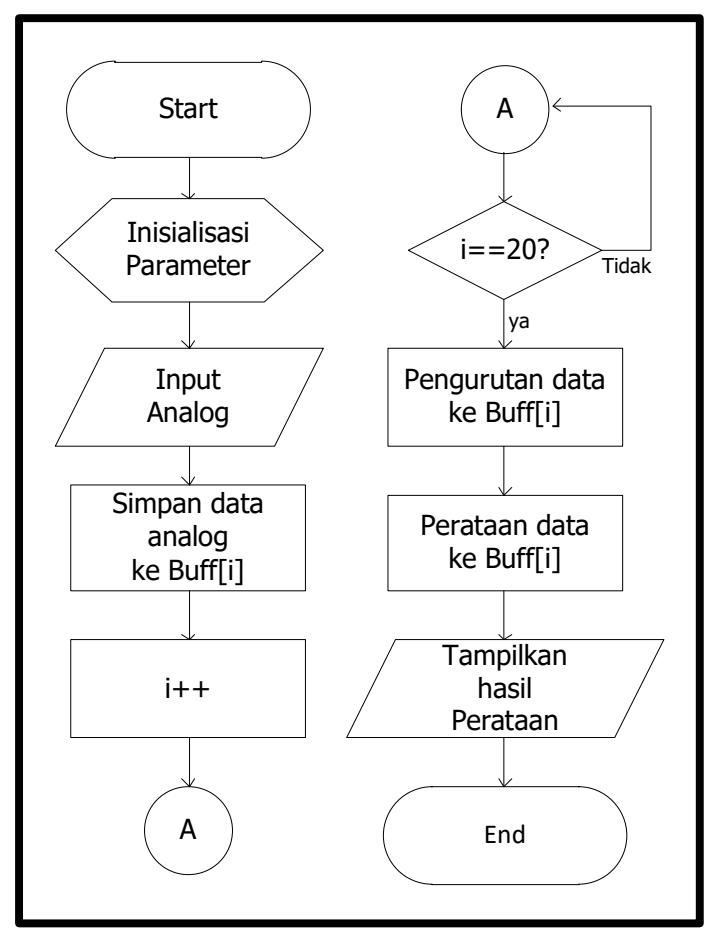

Gambar 5. Diagram Alir pH Meter (Banu, 2017)

Berdasarkan Gambar 5, diagram alir yang digunakan dalam perancangan sistem ini diantaranya sebagai berikut:

a. Inisialisasi Parameter. Pada proses ini dilakukan inisialisasikan nilai variabel dan konstanta yang akan digunakan

b. Input Analog. Data keluaran yang dihasilkan sensor $\mathrm{pH}$ berupa sinyal analog, menjadi data masukan pada mikrokontroler.

c. Simpan data analog ke Buff[i]. Simpan data analog pada buffer 'buff'.

d. $\mathbf{i}=\mathbf{= 2 0}$ ?, jika i telah mencapai 20, lakukan proses berikutnya, tetapi jika kurang dari 20, lakukan kembali proses sebelumnya.

e. Pengurutan data Buff[i]. Data yang tersimpan pada setiap elemen array 'buff' selanjutnya diurutkan mulai dari nilai terkecil hingga terbesar.

f. Perataan data Buff[i]. Data yang telah diurutkan selanjutnya diratakan dengan mengambil nilai ke-6 sampai dengan ke-15 kemudian dibagi 10.

g. Menampilkan data buff. Data yang telah diratakan, selanjutnya ditampilkan dalam format UART(Universal Asynchronous Receiver Transmitter).

\section{DATA PENGAMATAN DAN ANALISIS}

Proses pengujian yang dilakukan pada penelitian ini terdiri dari beberapa tahap. Pengujian pertama dilakukan pada rangkaian pengkondisi sinyal yang telah diimplementasikan. Pada proses ini, rangkaian pengkondisi sinyal yang terdiri dari IC CA3140AMZ dan IC TL081BCD64 diuji nilai tegangan yang dihasilkannya saat mengukur $\mathrm{pH}$ sebuah larutan. Proses pengukuran tegangan menggunakan AVOmeter Heles UX-866TR, sedangkan pada 
pengukuran $\mathrm{pH}$ dengan menggunakan $\mathrm{PH} / \mathrm{EC}-9853$. Larutan nutrisi yang diuji adalah campuran 10 liter air mineral yang ditambah larutan AB Mix hingga menghasilkan larutan nutrisi tanaman dengan nilai EC sebesar $2 \mathrm{mS} / \mathrm{cm}$. Parameter $\mathrm{pH}$ pada larutan nutrisi diatur nilainya dengan menambahkan larutan $\mathrm{pH}$ up ataupun $\mathrm{pH}$ down. Proses pengujian dilakukan secara berulang sebanyak lima kali. Satu kali proses pengujian yang dilakukan berupa proses pengukuran $\mathrm{pH}$ larutan nutrisi mulai dari 2 derajat keasaman sampai dengan 13 derajat keasaman dengan kenaikannya setiap 0,25 derajat keasaman. Berikut ini Gambar 6 yang memperlihatkan grafik hasil pengukuran berulang hubungan antara nilai $\mathrm{pH}$ dan tegangan output yang dihasilkan pada IC CA3140AMZ.

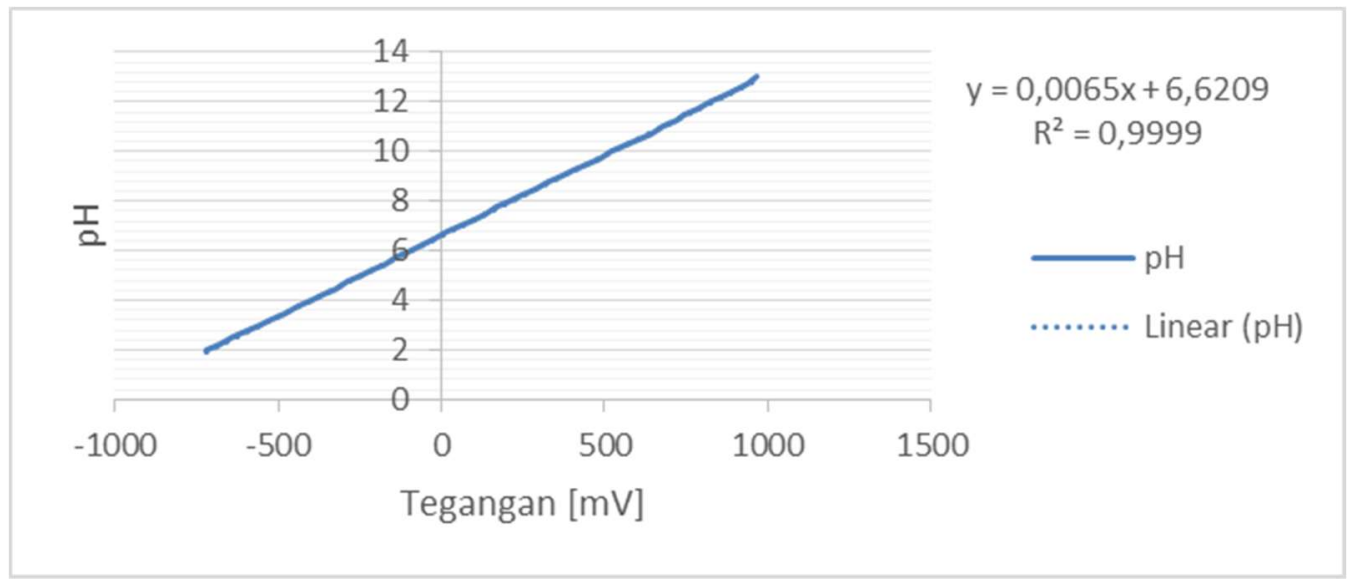

Gambar 6. Grafik Hubungan pH terhadap Tegangan pada IC CA3410AMZ

Grafik pada Gambar 6 merupakan nilai rata-rata dari hasil pengukuran berulang yang telah dilakukan sebanyak lima kali. Pada grafik tersebut, tampak bahwa koefisien determinasi yang dihasilkan adalah sebesar 0,9999 dengan persamaan regresi $\mathrm{y}=0,0065 \mathrm{x}-6,6209$ sehingga telah linier. Output yang dihasilkan oleh IC CA3140AMZ, selanjutnya menjadi input untuk IC TL081BCD64. Berikut ini Gambar 7, yang memperlihatkan hasil pengujian pada IC TL081BCD64 yang digunakan dengan banyaknya pengujian berulang yang dilakukan sebanyak lima kali.

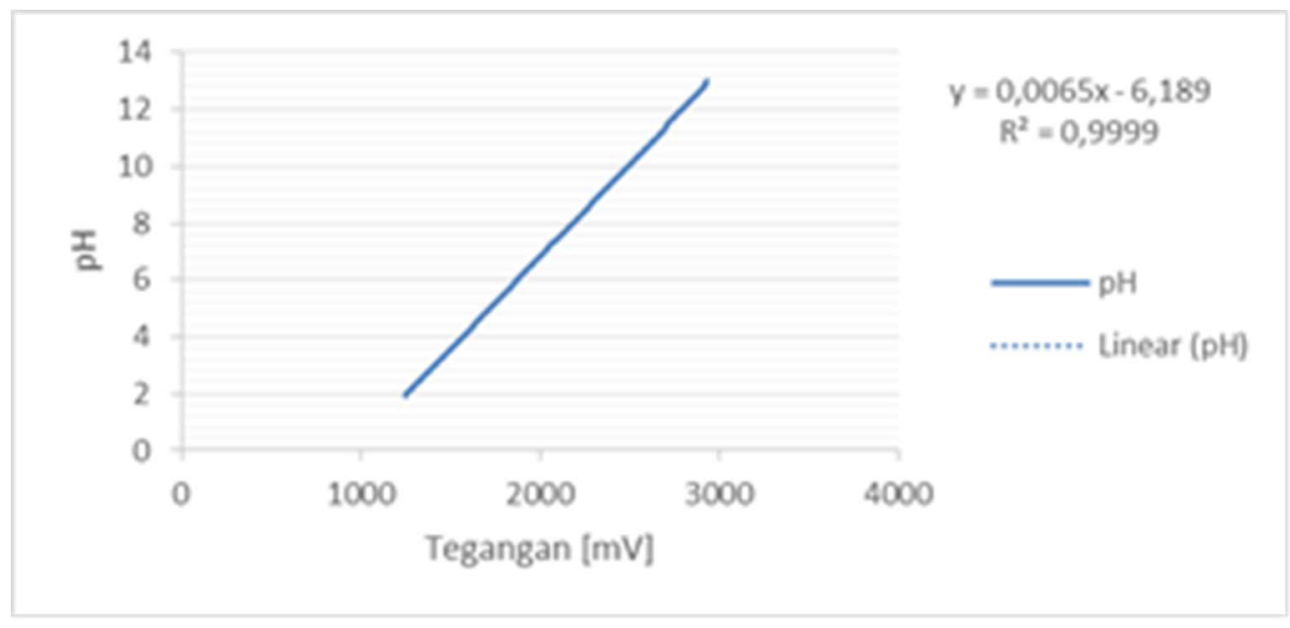

\section{Gambar 7. Grafik Hubungan pH terhadap Tegangan pada IC TL081BCD64}

Berdasarkan hasil pengujian tahap kedua pada Gambar 7, IC TL081BCD64 yang digunakan adalah berupa rangkaian amplifier yang berfungsi sebagai rangkaian summing. Penambahan 
nilai tegangan rata-rata yang diberikan pada output IC CA3140AMZ adalah sebesar 1970mV dengan menggunakan IC TL081BCD64 tersebut. Hal ini berfungsi untuk menghilangkan nilai tegangan negatif yang dihasilkan oleh IC CA3140AMZ, sehingga memungkinkan perangkat mikrokontroler untuk mengolah data tersebut. Koefisien determinasi yang dihasilkan oleh IC TL081BCD64 adalah sebesar 0,9999 dengan persamaan regresi $y=0,0065 x+6,189$, sehingga telah linier.

Pada proses pengujian yang kedua, adalah membandingkan hasil pengukuran $\mathrm{pH}$ sebuah larutan, antara perangkat $\mathrm{pH}$ meter yang telah dirancang dengan $\mathrm{pH}$ meter tipe $\mathrm{PH} / \mathrm{EC}-9853$. Persamaan regresi yang telah diperoleh pada gambar 7, digunakan pada realisasi perangkat lunak $\mathrm{pH}$ meter yang telah dirancang. Proses pengujian dimulai dari nilai $\mathrm{pH}$ larutan sebesar 2 derajat keasaman sampai dengan 13 derajat keasaman, dengan kenaikan nilai $\mathrm{pH} 0,25$ derajat keasaman setiap proses pengukurannya. Lama waktu pengujian kurang dari 24 jam, dengan banyaknya pengujian berulang yang dilakukan sebanyak lima kali. Berikut ini Gambar 8, yang menampilkan data hasil pengujian berulang pada tahap dua yang dinyatakan dalam bentuk grafik perbandingan antara sensor $\mathrm{pH}$ meter yang dirancang (FIT0348) dengan alat ukur pH/EC-9853.

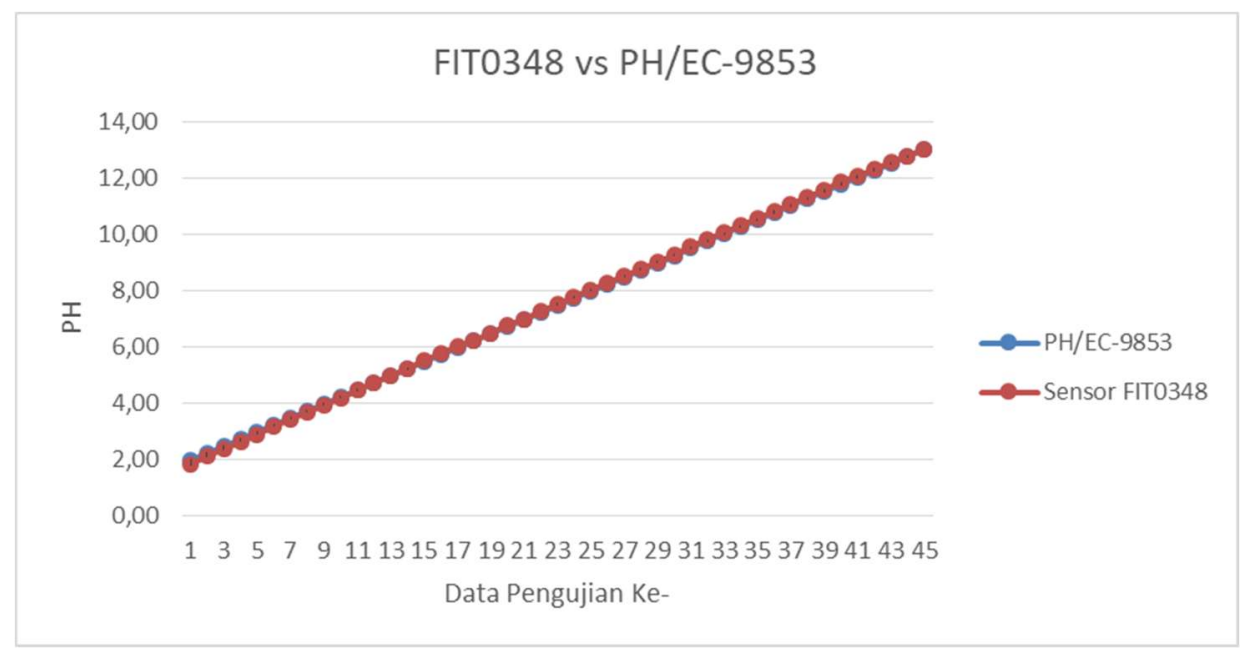

\section{Gambar 8. Grafik Perbandingan Hasil Pengukuran pH antara pH Meter PH/EC-9853 dan FIT0348}

Berdasarkan data hasil pengujian tahap 2, yang terdapat pada Gambar 8, menunjukkan bahwa nilai rata-rata kesalahan pengukuran yang dihasilkan oleh sensor FIT0348 yang diuji, terhadap pH meter PH/EC-9853 (yang diasumsikan sebagai nilai sebenarnya) adalah sebesar $\pm 0.05 \mathrm{pH}$.

Pengujian selanjutnya yaitu tahap ketiga dilakukan selama 7 hari dengan proses pencatatan hasil pengujiannya dilakukan setiap rentan waktu $\pm 24 j a m$. Pencatatan hasil pengukuran dilakukan secara berulang sebanyak lima kali dan diratakan hasilnya. Pengujian tahap ini dilakukan dengan tujuan menguji perubahan ketepatan sensor saat digunakan secara terusmenerus dalam waktu lebih dari 24 jam. Pada proses pengujian ini, perubahan nilai pH yang terjadi tidak diakibatkan oleh penambahan larutan $\mathrm{pH}$ up maupun $\mathrm{pH}$ down. Hal ini dikarenakan tujuan dari pengujian tersebut, adalah untuk mengetahui simpangan pengukuran yang terjadi setelah digunakan lebih dari 24 jam. Berikut ini Tabel 1, yang menunjukkan hasil pengujian ketiga yang telah dilakukan. 
Tabel 1. Hasil Pengukuran pH Selama 7 Hari

\begin{tabular}{|c|c|c|c|c|c|c|}
\hline No & Tanggal & Waktu & $\mathbf{\Delta t}$ & $\mathbf{p H / E C - 9 8 5 3}$ & FIT0348 & $\mathbf{\Delta p H}$ \\
\hline 1 & $24 / 09 / 2018$ & $20 ; 44$ & & 8,62 & 8,43 & $-0,19$ \\
\hline 2 & $25 / 09 / 2018$ & $13 ; 51$ & $17 ; 07$ & 8,99 & 8,78 & $-0,21$ \\
\hline 3 & $26 / 09 / 2018$ & $14 ; 13$ & $24 ; 22$ & 8,97 & 8,73 & $-0,24$ \\
\hline 4 & $26 / 09 / 2018$ & $16 ; 43$ & $26 ; 30$ & 8,97 & 8,73 & $-0,24$ \\
\hline 5 & $27 / 09 / 2018$ & $14 ; 42$ & $21 ; 59$ & 8,98 & 8,73 & $-0,25$ \\
\hline 6 & $28 / 09 / 2018$ & $20 ; 18$ & $29 ; 36$ & 8,98 & 8,72 & $-0,26$ \\
\hline 7 & $04 / 10 / 2018$ & $17 ; 28$ & $21 ; 10$ & 9,1 & 8,81 & $-0,29$ \\
\hline
\end{tabular}

Berdasarkan data hasil pengujian tahap ketiga pada Tabel 1, menunjukkan bahwa proses pencatatan data dilakukan secara berkala dengan rentan waktu antara 17 jam 07 menit s/d 29 jam 36 menit. Nilai pH yang ditampilkan pada Tabel 1, merupakan nilai rata-rata dari hasil pengukuran berulang alat ukur pH/EC-9853 dan FIT0348. $\Delta \mathrm{pH}$ merupakan simpangan pengukuran yang dihasilkan antara alat ukur pH/EC-9853 dan FIT0348. Berdasarkan hasil pengujian memperlihatkan semakin lama waktu pengujian yang dilakukan, simpangannya pun semakin besar. Terjadinya perubahan simpangan hasil pengukuran yang semakin besar setiap rentan waktunya diakibatkan oleh menurunnya ketepatan dari sensor pH yang digunakan. Nilai rata-rata penurunan ketepatan setiap harinya, yang dihasilkan berdasarkan total waktu pengukuran yang dilakukan selama 5 hari 20 jam 44 menit adalah sebesar $0,02 \mathrm{pH} / 24 \mathrm{jam}$.

Nilai rata-rata penurunan ketepatan yang telah dihasilkan pada pengujian ketiga tersebut digunakan untuk menentukan nilai konstanta kalibrasi yang digunakan pada $\mathrm{pH}$ meter FIT0348. Melalui proses perhitungan waktu internal yang dilakukan oleh perangkat mikrokontroler melalui fitur internal timer-nya, ketepatan pada sensor FIT0348 dirancang untuk bertambah sebesar $0,02 \mathrm{pH}$ setiap 24 jam. Selanjutnya dari hasil penambahan konstanta ketepatan tersebut, dilakukan pengujian keempat untuk mengetahui ketepatan akhir yang dihasilkan dari prototipe smart pH meter yang telah dirancang. Berikut ini tabel 2 yang menampilkan data hasil pengujian $\mathrm{pH}$ meter dengan rentan waktu pengujian selama 7 hari, yang telah ditambahkan nilai konstanta ketepatan.

Tabel 2. Hasil Pengukuran pH dengan Penambahan Kontanta Ketepatan

\begin{tabular}{|c|l|c|c|c|c|}
\hline No & Tanggal & Waktu & pH meter & sensor $\mathbf{~ p H}$ & $\mathbf{\Delta} \mathbf{p H}$ \\
\hline 1 & $05 / 10 / 2018$ & $12 ; 10$ & 8,55 & 8,53 & $-0,02$ \\
\hline 2 & $06 / 10 / 2018$ & $12 ; 15$ & 8,85 & 8,84 & $-0,01$ \\
\hline 3 & $07 / 10 / 2018$ & $12 ; 05$ & 8,98 & 8,97 & $-0,01$ \\
\hline 4 & $08 / 10 / 2018$ & $12 ; 08$ & 8,97 & 8,96 & $-0,01$ \\
\hline 5 & $09 / 10 / 2018$ & $12 ; 02$ & 8,98 & 8,96 & $-0,02$ \\
\hline 6 & $10 / 10 / 2018$ & $12 ; 06$ & 8,96 & 8,94 & $-0,02$ \\
\hline 7 & $11 / 10 / 2018$ & $12 ; 05$ & 9,10 & 9,09 & $-0,01$ \\
\hline
\end{tabular}

Berdasarkan data hasil pengujian pada Tabel 2, hasil pengukuran yang ditampilkan pada tabel tersebut merupakan nilai rata-rata dari pengukuran berulang yang telah dilakukan. smart $\mathrm{pH}$ meter yang dirancang telah sesuai dengan spesifikasi yang diharapkan untuk pengukuran $\mathrm{pH}$ pada rentan nilai 8 sampai dengan 9 derajat keasaman. Hal ini dapat terlihat dari simpangan nilai pH yang dihasilkan menjadi lebih kecil dan tidak bertambah nilainya setiap lebih dari 24 jam. Meskipun telah cukup baik, namun tetap perlu dilakukan proses 
pengujian kembali secara berulang dengan pengukuran nilai pH yang lebih bervariasi, untuk menghasilkan nilai yang lebih tepat kembali.

\section{KESIMPULAN}

Berdasarkan hasil pengujian tahap pertama pada rangkaian pengkondisi sinyal yang digunakan, rangkaian yang telah dirancang memiliki koefisien determinasi sebesar 0,9999 dengan persamaan regresi $y=0,0065 x+6,189$. Rangkaian amplifier yang digunakan sebagai pengkondisi sinyal tersebut memiliki kelinieran yang baik sehingga mempermudah perangkat mikrokontroler dalam mengolah data hasil pengukuran untuk menghasilkan output yang lebih akurat. Penambahan algoritma pengkondisi sinyal pada perangkat mikrokontroler yang digunakan di $\mathrm{pH}$ meter, mengakibatkan besarnya penurunan ketepatan derajat keasaman dari sensor FIT0348 berubah dari $0,02 \mathrm{pH} / 24$ jam menjadi tidak terjadi penurunan derajat keasaman setiap pemakaian lebih dari 24 jam. Tidak terjadinya penurunan ketepatan derajat keasaman tersebut telah baik untuk proses pengukuran pada rentang nilai $\mathrm{pH}$ antara 8 sampai dengan 9 derajat keasaman, dengan lama waktu pemakaian selama 1 minggu. Hal tersebut disebabkan lama waktu proses pengujian prototipe alat ukur yang telah dilakukan hanya dalam waktu 1 minggu. Kesalahan pengukuran yang dihasilkan oleh prototipe $\mathrm{pH}$ meter yang telah dirancang adalah sebesar $\pm 0,01$ derajat keasaman, terhadap alat ukur $\mathrm{PH} / \mathrm{EC}-9853$ yang digunakan sebagai pembandingnya.

\section{DAFTAR RUJUKAN}

Roidah, \& I., Syamsu. (2014). Pemanfaatan Lahan Dengan Menggunakan Hidroponik. Jurnal Universitas Tulungagung BONOWORO, 1.

Shahrulakram, M., A., I. \& Johari, J. (2016). Water Storage Monitoring System with pH Sensor for Pharmaceutical Plants. IEEE 6th International Conference on System Engineering and Technology (ICSET).

Canals, I., Portal, J., A., Bosch, E., \& Roses, M. (2000). Retention of ionizable compounds on HPLC. 4. Mobile-phase pH measurement in methanol/water. Anal. Chem. 72(8), 1802-1809.

Taufiqullah. (2017). Faktor Yang Menentukan Nilai pH Air. Retrieved from www.tneutron.net/blog/faktor-yang-menentukan-nilai-ph-air/.

ONNY. (2017). Prinsip Kerja pH Meter. Retrieved from artikel-teknologi.com/prinsip-kerja-phmeter/.

Jun, Li, Frank, Albri, Robert, R., J., Maier, Wenmiao, Shu, Jining, Sun, Duncan, P., Hand, \& William, N., MacPherson. (2015). A Micro-Machined Optical Fiber Cantilever as a Miniaturized pH Sensor. IEEE Sensors Journal, 15(12), 7221-7227.

Dfrobot. (2017). Industrial $\mathrm{pH}$ electrode (SKU:FIT0348). Retrieved from www.dfrobot.com/wiki/index.php/Industrial_pH_electrode(SKU:FIT0348). 
Anwari, S. (2017). Kalibrasi Sistem Pengukuran. Seminar Nasional Energi Telekomunikasi dan Otomasi (SNETO), (pp. 1-7).

Sudewa, B. \& Hadiatna, F. (2017). Evaluasi Sensor FIT0348 Sebagai Alat Ukur Potensial of Hydrogen (pH) Larutan. Jurnal Elektro dan Telekomunikasi Terapan (JETT), 4(2). 